\title{
A Study of Financing Risk Management in Land Reserve
}

\author{
Yanfeng Yang ${ }^{1, a}$ and Junqi Xie ${ }^{1, b}$ \\ ${ }^{1}$ School of Land Science and Technology, China University of Geosciences(Beijing) \\ Beijing 100083, China \\ ayanfengyang@126.com, bghyxjq@163.com
}

Keywords: Land Reserve, Risk Management.

\begin{abstract}
The land reserve was introduced to China twenty years ago. It stimulates the real estate markets and accelerates the urban development as well as economy developing. Financing risks are concerned much during the course of land reserve development, due to their characters of huge in scale, long payment periods and difficulties of repayment. Some financial tools including bank loans, entrusted loans and insurance funds become common methods of funding for the land reserve. This paper analyses the land reserve project costs in Beijing from 2001 to 2014 and categorizes the current financial risks as following four types: policy risk, interest rate risk of commercial banks, scale risk, and project operation risk. It suggests to establish a model of financing risk management on land reserve, which will include 'establish warning mechanism', 'extend the financing channels', 'adopt quantitative managements' and 'improve and enhance internal controls'.
\end{abstract}

\section{Introduction}

The land reserve refers to a kind of 'private land reserve' by investors on micro- perspective. It means 'public land reserve' from a view on government's sectors in this essay. The private land reserve is designed to overcome the obstacles of uncertainty and incomplete market. The public land reserve, however, is mainly to make the city more compact and rational development rather than its sprawling [1].The purpose is to guide the cities' growth reasonable and promote the cities development sustainable [2, 3]. The corporation of financial instruments with financial tools can give the execution of land reserve an essential capital guaranty[4].

There have been financing risks that show a trend of diversification and complication while the financing tools developed[5-7].The essay analyzes the financing risks based on the specific land reserve cases in Beijing. It tries to understand the schema and explore the financing risks of land reserve. Finally it develops a systematic methodology for reducing the impacts of financing risks on the economics and society.

\section{Analysis of financing risks of land reserve}

Beijing is one of the biggest cities in China. The population of permanent resident is more than 20 million by the end of 2015, with its total area of 1,600 square kilometers. According to the urban planning, it is divided into 4 major functional areas, namely, the core areas of urban functions, functional development zones, the new development zones and ecological conservation development zones. Beijing has established land reserve system to meet the development requirements of the 4 functional zones since 2001.

\section{The current land reserve and financing analysis}

The current land reserve has being completed since its setup. It is developing the land transaction and meeting the needs of lands by many sectors such as residential apartments, commercial sites and industrial factories. The data in Table 1 and Figure 1 shows the structures of lands provided by land reserve. 
Table 1 Statistics of state-owned construction land market trade transaction

\begin{tabular}{ccccccc}
\hline Year & Transactions & \multicolumn{3}{c}{ The Type of Land Trade } & Area & Transaction price \\
& & 1 & 0 & 0 & 13.97 & 3.17 \\
\hline 2001 & 1 & 2 & 1 & 5 & 250.48 & 61.35 \\
2002 & 8 & 3 & 1 & 44 & 201.70 & 49.14 \\
2003 & 48 & 4 & 0 & 85 & 537.92 & 115.31 \\
2004 & 89 & 2 & 0 & 48 & 357.39 & 117.51 \\
2005 & 50 & 29 & 1 & 57 & 856.20 & 257.67 \\
2006 & 87 & 41 & 0 & 44 & 897.92 & 438.1 \\
2007 & 85 & 26 & 0 & 158 & 1573.43 & 500.12 \\
2008 & 184 & 20 & 1 & 229 & 1965.16 & 966.28 \\
2009 & 250 & 81 & 0 & 199 & 3012.04 & 1677.27 \\
2010 & 280 & 52 & 0 & 205 & 2044.54 & 1113.29 \\
2011 & 257 & 27 & 0 & 142 & 1340.40 & 670.61 \\
2012 & 169 & 53 & 0 & 170 & 2118.64 & 1853.15 \\
2013 & 223 & 16 & 0 & 125 & 1295.20 & 1916.90 \\
2014 & 141 & 357 & 4 & 1511 & 16465.07 & 9739.87 \\
Total & 1872 & & & &
\end{tabular}

According to statistics, the residential area accounts for $46 \%$, industrial area is $36 \%$ and the left $18 \%$ is commercial area on land trading market between 2009 and the end of 2014 in Beijing.

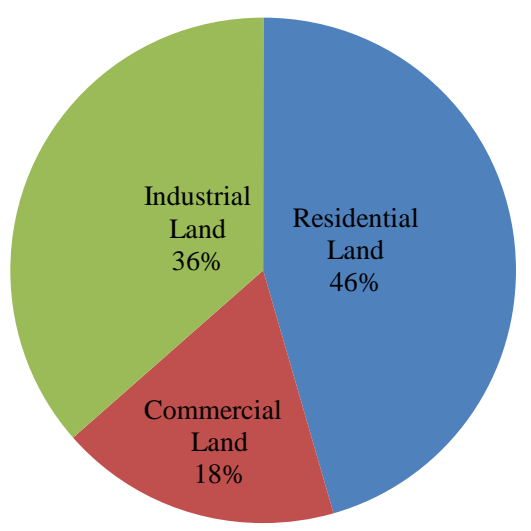

Fig.1 Statistics of land transfer usage types during 2009 to 2014 in Beijing

These huge land reserves cost a lot of capital investment on the land primary acquisition. The cost analysis indicates that the costs may include the land compensation fees, relocation compensation costs, and unforeseen financial expenses. These three kinds of cost accounts for $98 \%$ of all expenditures according to most of the land reserve projects.

In order to invest the projects of land reserve the project subjects need to find the sources of the capital investments. Bank loans, entrusted loans and insurance funds are the common financing means in Beijing. Among them the loans from commercial banks account for $67 \%$ of the total amount. The trust funds and insurance funds account for about other left $23 \%$ nearly four years.

\section{The financing situation and risk analysis}

The risks always exist during the funding of the projects of the land reserves. The debt of bank loans should be provided year by year. This risk also derives a series of risks.

Slow return of land reserve funds \& continuous high level of the city's debt. The land reserve agency's debt has remained at 200 billion CNY since 2011.The huge size of the debts lead to the 
continuous increase of the cost of capital. It has also leads to the limited space which the land reserve institutions adjust itself to the project cost.

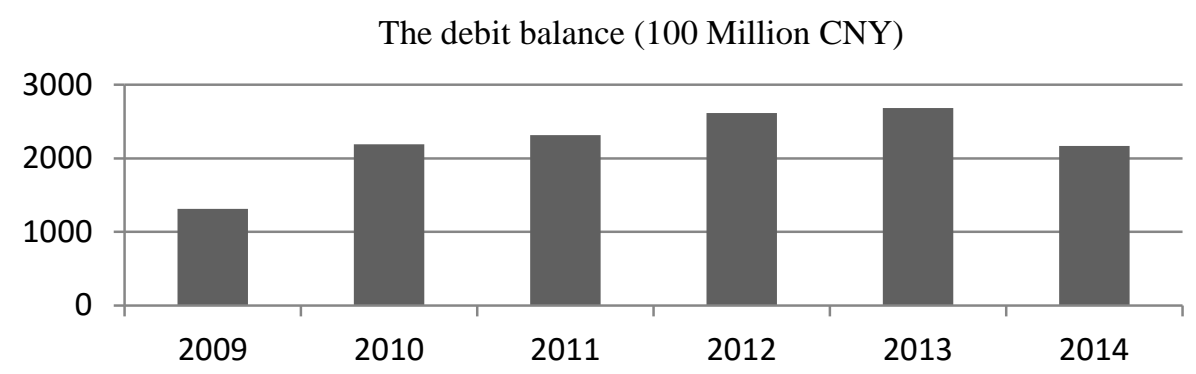

Fig.2 Debts balance of Beijing's land reserve

Imbalance and low rates of capital return. The debts should be balanced by continuous providing selling the parcels of lands with infrastructural maturity. This needs the land markets well developed.

Table 2 The average capital returns analysis during 2009-2012

\begin{tabular}{clccc}
\hline No. & \multicolumn{1}{c}{ Area } & $\begin{array}{c}\text { Invested Volume } \\
(100 \text { Million CNY })\end{array}$ & $\begin{array}{c}\text { Capital returns } \\
(100 \text { Million CNY) }\end{array}$ & Capital returns ratio \\
\hline 1 & Core functional & 38.66 & 0 & 0 \\
2 & Functional development & 177.88 & 80.38 & $45.19 \%$ \\
3 & New development & 722.94 & 289.23 & $40.01 \%$ \\
4 & Ecological conservation & 176.36 & 24.61 & $13.95 \%$ \\
& development & 1115.84 & 394.22 & $35.33 \%$ \\
\hline
\end{tabular}

It has been invested 111.6 billion CNY by the land reserve agencies from 2009 to the end of 2012. Only 39.4 billion CNY reclaiming funds have been collected. The return of investment is 35.33\%, which is far lower than the expectation.

The return of funds kept as low as 0 in the core area of urban functions due to the demolition challenge. However, it gained high capital return in the functional development zone because of its completed infrastructures such as educational and medical facilities as well as good location and other characteristics. It got relatively promptly return the funds in the new urban development zone with the fast speed of developing.

\section{The costs of land reserve continue to rise.}

Cost of land reserve (CNY/sq.m)

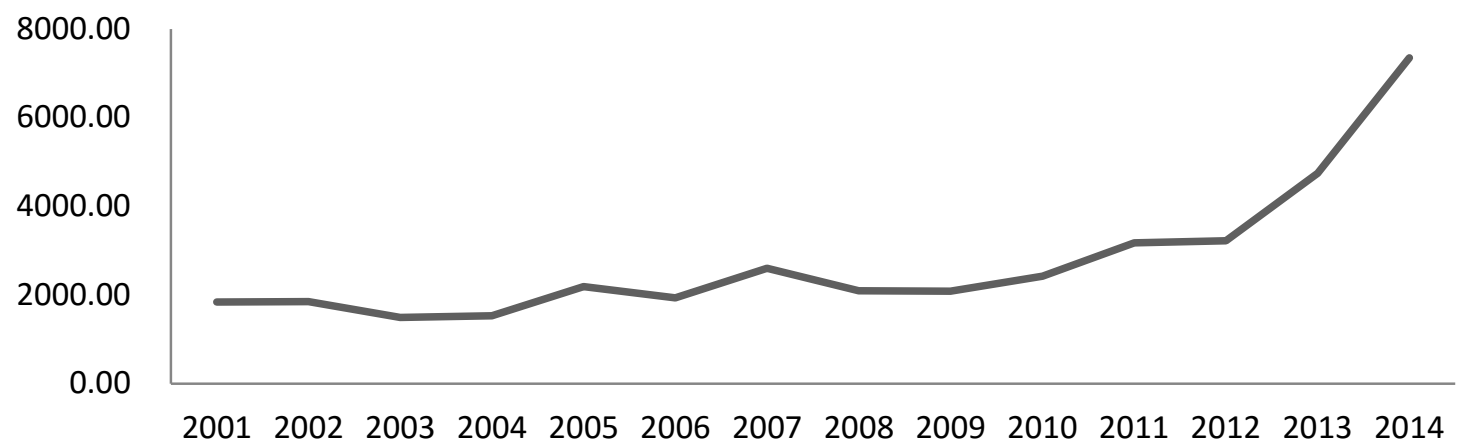

Fig. 3 Land reserve costs during 2001-2014 in Beijing

In order to balance the costs, the lands should be provided to the market continuously. The data shows that 1872 cases with 164,647,900 square meters were transacted form 2001 to 2014. These transactions returned 9739.97 billion CNY. From this data, the average annual land reserve cost can be figured out by the total income misusing the government revenue. It is shown in the Fig. 3 that the cost of land reserve has continued to grow year by year. Especially the costs remained much high in 
the last two years. The cost of land reserve increased by $54.77 \%$ in 2014 comparation with that in 2013.

The increasing cost of the single project. The mortgages from commercial banks are the major financing sources for land reserve. The medium and long term loans take the most proportion. Interest costs are correspondingly higher which brings direct financing pressure to land reserve agencies.

Financing risks of the land reserve. Land reserve encounters the risks coming from bank interest rates easily. This may produces cost risks and policy risks along with the long period of the project implementation and slow return of the funding. Funds of selling the land always cannot return on time, which may lead to increase the costs while the project does not match the actual progress of the development plan.

For the single project, the costs of the reserve project also met certain risk, such as long implementing period and the costs of large scale operating, and the project maintaining.

\section{The risk management of land reserve financing}

The methodology of Enterprise Risk Management is useful for the risk management in the area of land reserve. This method may include 5 steps. They are setting up goals, identifying risks, evaluating the risks, implementing programs to erase or mitigate the risks and monitoring the progresses. As for erasing or mitigating the risks, the paper suggests as follows:

Establish warning mechanism by more initiatives. There are many initiatives to control the financing risks. First of all, the financial pressure can be reduced by digest the stock. Secondly, continuously supply of lands to the market may get more repayments to reduce financing costs. Thirdly, the loans structure can be adjusted by using other financial tools such as more short-term loans.

Two aspects should be considered for establishing warning mechanism. Firstly, the waves of land price should be monitored by setting up a warning system. This may be done through ongoing the land price evaluation system, which can track the land price fluctuation with the land market changing quarterly. Secondly, the land reserve agencies need to track the progress of execution of the project. It should be actively establish by the special reminder linkage mechanism with relevant departments.

Broaden the financing channels. At present the funds for land reserve mainly come from the loans of commercial banks. This may lead risks both for the land reserve agencies and for banks. Broadening the financing channels through using other sources is a pressing matter of the moment. The new land reserve model can be set up by a 'joint disciplines'. The governments act as 'leadership and the private sectors as partners. This is a kind of comprehensive land reserves, which optimizes the allocation of different resources. Social capital from private sectors can play an important role in land reserve system from practical view. It should be motivated that the social capital participates in the land reserve. And it is very necessary to establish a mechanism that corporate profits and the operating cycle linked.

Establish a kind of a land reserve foundation is another way to broaden the channels of investment for land reserve. The foundation can be raised through public or private placement from the public investors or institutions. The implementation of the division of labor and specialized management of the collection of investment can be act as stock rights. This foundation can be managed by professional team under 'collective division'. The foundation can reduce the financing costs. As a result it can effectively reduce the risk of land reserve that institutions used to face to. It is can be named 'risk sharing, profit share'. This also could be an opportunity that the investments from private sectors can be involved in public area.

The other way to share the risks is to take the enterprises as the main subject for the development of land reserves. This will not only ease the land reserve fund pressure and improve the utilization of funds efficiently, but also speed up the pace of land reserve project.

Adopt quantitative management. Quantitative management is an accurate way to deal with the risks of land reserve. This will focus on analyzing the costs and optimizing the process precisely. It 
can save time cost and capital cost of land reserve project by using data and models to calculate each risk.

Improve and enhance internal controls. The internal control is a kind of precise management within an enterprise or a single project. Under this instrument, all participants are needed to under control by different managers while they are employed themselves in the land reserve project. It is needed to develop and enhance the interdependence and mutual restraint relationship between the financial unit, discipline inspection and supervision and internal audit.

It should be a specific responsibility for all employees to do risk management. This should be the key business of the managers.

Every individual is an important node in the internal control. Everyone should be realized from "I was needed for internal control" to "I want to DO internal control". The long-term internal control mechanism should be established fundamentally.

\section{Conclusion}

It can be finally categorized the current financing risks into four types based on the specific cases in Beijing, policy risks, interest rate risks of commercial banks, scale risks and project operation risks. This paper suggests to establish a risk management model for controlling these risks in the area of land reserve, which includes 'establish warning mechanism', 'broaden the financing channels', 'adopt quantitative management' and 'enhance internal management'. This can reduce the financing risk impact in order to make better service for the whole society through land reserve.

\section{References}

[1] B.D. Bi: Land Economics (the RMU publishing, China 2009), p.173.

[2] Harold, B. Dunkerley: Urban Land Policy: Issues and Opportunities (Oxford University Press, U.K 1983).

[3] Heap: Introduction the Land Commission Act (Sweet \& Mexwell, U.K 1967).

[4] J.T. Wang and H.Z. Zhang: The Successful Experience and its Lesson of Overseas Land Reserve System in Operations: Transactions of Shanghai Technical College Of Urban Management, (2006), No.4,p.A51-A55.

[5] H.Z. Li: Financial Management of the Land Reserve Funds: Theory Induction, International Experience and Reform Path (Ph.D., Dongbei University of Finance and Economics, China 2011).

[6] J. Yang: The Research in Risk Management of Land Reserve (Ph.D., Tongji University, China 2006).

[7] Y. Chen: Study on Financial Risk Evaluation of Land Banking - a County Land Banking Center for Example (M.S., Sichuan Agricultural University, 2011). 